\title{
The Role of Portfolio Assessment in Enhancing the Moroccan EFL Students' Writing Self-concept
}

\author{
Elmostafa Omarakly \\ Ibn Zohr University, Morocco \\ mostafaomarakly@gmail.com \\ Youssef Tamer \\ Ibn Zohr University, Morocco \\ y.tamer@uiz.ac.ma
}

DOI: http://doi.org/ 10.36892/ijlls.v4i1.800

\begin{tabular}{|c|c|}
\hline $\begin{array}{l}\text { Received: } \\
\text { 01/01/2022 }\end{array}$ & $\begin{array}{c}\text { Abstract } \\
\text { Since the birth of humanistic approaches to language teaching and learning, }\end{array}$ \\
\hline $\begin{array}{l}\text { Accepted: } \\
\text { 25/01/2022 }\end{array}$ & $\begin{array}{l}\text { researchers and practitioners directed special attention to various } \\
\text { psychologicalfactors that interfere with students' learning. The purpose of this } \\
\text { study is to investigate the role of portfolio-based assessment practices in } \\
\text { enhancing students' writing self-concept. The study further explores the }\end{array}$ \\
\hline $\begin{array}{l}\text { Keywords: } \\
\text { Portfolio Assessment, } \\
\text { Summative Tests, } \\
\text { Self-concept, } \\
\text { Students'Attitudes. }\end{array}$ & $\begin{array}{l}\text { students' perceptions of portfolio assessment in relation to their writing self- } \\
\text { concept. To achieve these objectives, the study relied on a mixed-method } \\
\text { research design with a sample of two independent groups (classes) of high } \\
\text { school students. One group followed portfolio-based writing assessment } \\
\text { activities with various reflection techniques, while the other group stuck to the } \\
\text { regular summative-based writing tests. The results indicate a statistically } \\
\text { significant difference }(p<.005) \text { between the two groups' level of writing self- } \\
\text { concept in favor of the portfolio assessment group. The results also reveal a } \\
\text { gradual, though statistically non-significant, improvement in the portfolio } \\
\text { assessment group students' writing self-concept compared to that of the } \\
\text { traditional assessment group. On the other hand, the majority of the } \\
\text { participants were highly positive about portfolio assessment and its impact on } \\
\text { their writing self-concept. }\end{array}$ \\
\hline
\end{tabular}

\section{INTRODUCTIONAND LITERATURE REVIEW}

Writing remains one of the most complex and highly demanding language skills for learners, mainly foreign language learners. In order to be able to write, learners need to possess control over a number of interdependent variables simultaneously (Bell and Burnaby, 1984). These include "the ability to use structures, the lexical items, and their conventional representation in ordinary matter-of-fact writing" (Lado, 2000, p. 248). Nevertheless, mastering these skills does not always guarantee a 'good' writing performance. Hyland (2003) explains that the wide range of skills and knowledge that writing involves makes it unlikely that the same individual will perform equally well across different occasions and tasks. This is due to the multifarious cognitive and linguistic aspects involved in writing on the one hand and the numerous affective and psychological variables that interfere with the quality of students' performance on the other. Humanistic psychologists like Maslow (1943), Rogers (1957), and Krashen (1988) stress that learners can not reach their full potential unless they feel safe and confident in what they are doing. Empirical studies acknowledge that when psychological threats like anxiety and apprehension, and mistrust increase, students' writing engagement and 
performance levels are negatively affected (Badrasawi, Zubairi, \& Idrus, 2016; Boening, Anderson, \& Miller, 1997; Erkan \& Saban, 2011; Pajares, 2003; Valentine, Dubois, and Cooper, 2004; Yassin \& Razak, 2018). Still, studies in various contexts unveiled that most EFL learners suffer from low levels of writing confidence and experience substantial anxiety and apprehension levels (Elif, \& Yayli, 2019; Erkan \& Saban, 2011; Badrasawi, Zubairi, \& Idrus, 2016; Boening, Anderson, \& Miller, 1997; Öztürk \& Çeçen, 2007; Qadir, Bensen Bostanci \& Kurt, 2021). Correspondingly, several voices have been raised to redirect attention to the learners and get rid of pedagogical practices that undermine their learning (Saeed et al., 2021). In Morocco, calls to redirect the focus toward more healthy pedagogical approaches and methods have been reiterated by researchers and experts in numerous publications (Abouabdelkader \& Bouziane, 2016; Bouziane \& Zyad, 2018; Melouk, 2001; Ouakrime, 2000). Nonetheless, not much has changed at the level of practice up to date (Abouabdelkader \& Bouziane, 2016; Melouk, 2001; Ouakrime, 2000; Ghaicha, \& Omarakly, 2018). Most educational institutions continue teaching and testing students according to the existing traditional restrictions, which often result in higher levels of writing anxiety and apprehension among students and deprive them of genuine opportunities for positive writing self-concept building.

Self-concept is a general term that is used to describe how one feels about himself or herself. The concept is commonly defined as the sum total or average of one's beliefs and perceptions about himself or herself, variously referred to as global self-concept, self-worth, or self-esteem (Byrne, 1984; Harter, 1998; Mercer, 2011; Rosenberg, 1965). These beliefs and perceptions are formed through one's experience with and interpretation of the surrounding environment and are influenced particularly by reinforcements, evaluations of significant others, and one's attributions for one's behavior (Shavelson et al., 1976). Shavelson et al. provided a more detailed and concrete description of the construct known as "the Shavelson self-concept model," which is among the significant references for most contemporary studies on self-concept. This model consists of a general self-concept and other more specific selfconcepts. The general self-concept appears at the apex of the model. It is divided into academic self-concept, which is divided into particular subject areas as mathematics, English, etc., and non-academic self-concept, which is divided into social, emotional, and physical self-concept, which, in turn, are split into more specific self-concept components as represented in Figure 1. The authors further characterize the concept as (a) an organized or structured construct in that people categorize the different experiences and statements they have about themselves; (b) multifaceted in that the particular facets reflect the category system adopted by a particular individual and/or shared by a group; (c) hierarchical with a general self-concept at the apex and individual experiences in particular situations at the base of the hierarchy; (d) stable at the top of the hierarchy, but more susceptible to change at the lower levels of the hierarchy; (e) developmental as it becomes increasingly multifaceted as the individual develops from infancy to adulthood; (f) it has both descriptive and evaluative aspects in that the individual does not only develop a description of himself in a particular situation, but he also forms evaluations of himself in these situations; $(\mathrm{g}$ ) it can be differentiated from other constructs which it is theoretically allied to like academic performance. 
Figure 1: Structure of self-concept (Shavelson et al., 1976).

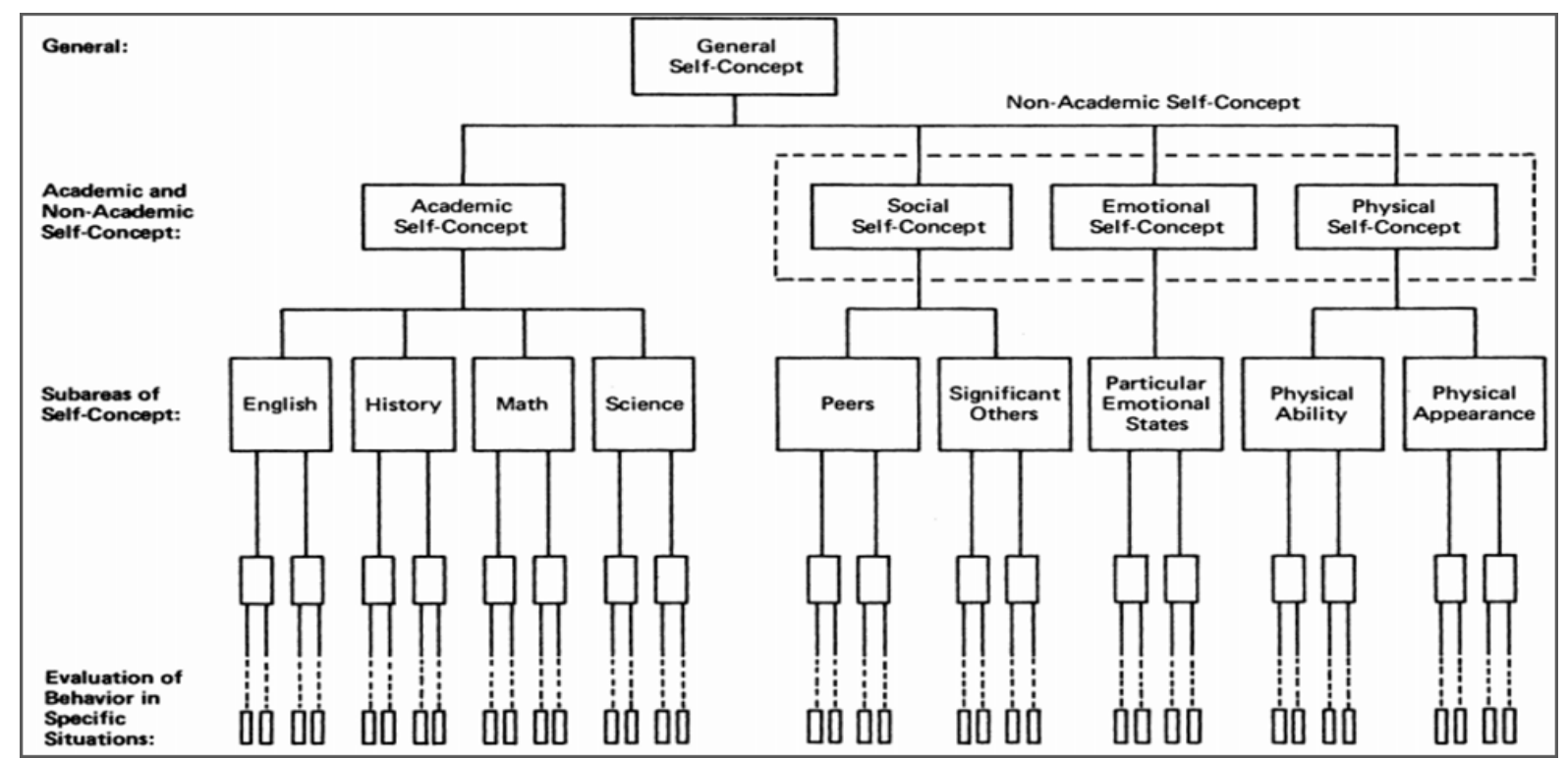

Teachers often strive to create a comfortable learning atmosphere where students feel respected and valued. However, learners tend to draw conclusions about themselves based on their final grades and their peers' achievements, which might negatively affect their self-image. Long-term, process-oriented assessment practices like portfolio assessment are believed to provide students with better opportunities to focus on their efforts and progress and build their confidence to write and resist the multi-linguistic and strategic difficulties they might encounter while writing. Portfolio assessment, as highlighted by several researchers, focuses on the student's efforts, progress, or achievement in (a) given area (s) and encourages them to track their learning through ongoing collection and reflection upon their work (Arter \& Spandel, 1992). Klenowski (2002) states that the process of portfolio development is an educative process in itself. (a) It requires students to collect more than one performance produced under the writer's usual circumstances; (b) it enables them to write and to be assessed in a variety of forms for a variety of purposes and audiences; (c) it provides a rich context where assessment, instruction, and the learners' past experiences are linked; (d) it delays evaluation and gives students time and motivation to revise and edit their writings before the final evaluation; (e) it encourages students to select the products that best represent their writing abilities; (f) it gives students a sense of control over their work; (g) it gives students opportunities to gain rich and multiple types of feedback; (h) it helps to track students' progress in different areas and measure their progress over time (Hamps-Lyons \& Condon, 2000). Nevertheless, the development and implementation of portfolios vary quite significantly depending on why and how it is put into practice.

The interconnection between portfolio-based writing assessment practices and students' writing self-concept is approached from different perspectives using different research designs. Burch (1999) explored the first-year composition students' experiences with and attitudes toward the effectiveness of portfolio assessment using questionnaires and interviews. Two groups of students were recruited to participate in the study, one group received portfolio 
assessment, and the other was received traditional instruction and assessment. This study demonstrated that the portfolio students were more positive about their writing abilities and showed more confidence for future college writing tasks than the non-portfolio students. Following a similar methodology, Lucas (2008) and Kathpalia and Heah (2008) probed into the different possible ways portfolio assessment can serve the students' communicative competencies in reading and writing. Analyzing the participants' reflective essays and comments, the researchers in both studies confirmed the effectiveness of portfolio assessment in enhancing the students' perceptions of their linguistic, cognitive, affective, and social competencies. Nicolaidou (2012) addressed the question of whether or not portfolio assessment could result in any significant positive impact on elementary students' writing self-efficacy. The study involved an experimental group of 63 students and a control group of 84 students. The experimental group relied on portfolio, whereas the control group proceeded conventionally. Comparing the two groups' levels of writing self-efficacy before and after the study, the researcher concluded that the portfolio assessment group experienced a significant writing self-efficacy improvement. At the same time, there was no substantial change in the control group's writing self-efficacy. Along the same lines, Ozer and Tanriseven (2016) examined the effectiveness of portfolio-based writing assessment activities in promoting EFL learners' writing skills and writing self-efficacy. This study included 32 and utilized different methods of data collection tools, including a portfolio scoring rubric, self-efficacy scale, and focus-group interviews. The results show the students' writing scores significantly increased, whereas there was no statistically significant difference in the levels of self-efficacy after portfolio assessment implementation. Nonetheless, the student's remarks adhered to an increase in the students' writing confidence.

In light of the literature above, it becomes apparent that portfolio assessment is generally perceived to be of great usefulness in building and maintaining a more positive writing selfconcept than other traditional forms of evaluation. Nevertheless, portfolio assessment might not always be as productive as expected. As detected in the quantitative findings of Ozer and Tanrıseven's (2016) study, there was not a statistically significant difference in the students' writing self-efficacy after receiving portfolio assessment. This study aims to provide further evidence on whether or not portfolio assessment can have any significant positive impact on the students' writing self-concept compared to other traditional summative modes of writing assessment through investigating the case of Moroccan EFL students. Furthermore, the study will look at how Moroccan EFL students perceive portfolio assessment to impact their writing self-concept. Accordingly, the following two major research questions were raised:

1. Does portfolio assessment have any significant impact on the Moroccan EFL students' writing self-concept?

2. How do the Moroccan EFL students perceive portfolio assessment in relation to their writing self-concept?

\section{METHODOLOGY}

To address the questions above, the study utilized a mixed-methods research design with both quantitative and qualitative methods of data collection and analysis. This mixture of research methods, according to many researchers, offers a better understanding of the research problem and question under examination than either method by itself (Creswell, 2005, Dawson, 
2007). The quantitative part of the study intended to measure the differences in the level of writing self-concept between the two groups involved in the study and examine the improvements made by each group between the pre- and the post-stages of the study. Concerning the qualitative part of the study, it aimed to re-examine the research questions from the qualitative point of view and see how it relates to the quantitative findings.

\subsection{Participants}

The sample of the study consisted of 48 who were members of two separate common core classes. Each class included 24 participants. Of the 48 students, 21 were males and 27 were females. The participants' age ranged between 15 and 17 years old. They all belonged to low- and middle-class families and appeared to possess a similar level of language proficiency according to the results of the ninth grade. Prior to the study, one class was randomly assigned as the experimental group, while the other was randomly assigned as the control group.

\subsection{INSTRUMENTS}

The study relied on two basic instruments in the process of data collection, namely selfconcept scale and students' written reflections. The writing self-concept scale was developed by Badiozaman's (2012) and is substantially grounded on the well-known Self-Description Questionnaire I by Marsh, Relich, and Smith (1983) and the Self-Description Questionnaire II by Marsh (1990) along with the Perception of Ability Scale by Boersma and Chapman (1977), but with more discipline-specific items. This questionnaire consists of 18 statements, including negatively worded items. The items tried to measure students' academic self-concept by substituting the school subject portion of the original scales' items with statements of more relevance to the academic writing domain. The current study adopted the same principle. It adapted the questionnaire's items so as to measure the participants' writing self-concept, but with more skill-specific items appropriate for the target sample and the purpose of the study, which is targeting the Moroccan EFL students' common core writing classes. Hence, using items such as "writing in English subject is one of my best skills" instead of "academic writing is one of my best disciplines". The items' response scale ranges from false and mostly false, which signify negative or lower levels of writing self-concept, to mostly true and true, which indicate positive or higher levels of writing self-concept. The items in the questionnaire and the response options were simplified and translated into the Arabic language before they were piloted in context to grant a more valid interpretation of the various items from the students' part and check their reliability and practicality. Overall, the questionnaire exhibited no issues during its implementation and showed significant levels of reliability in the piloting and the main study, which reached .90 .

The written reflections, on the other hand, aimed at tapping the students' views about the effectiveness of portfolio assessment practices in the Moroccan EFL writing classes. Given the concern that students might be subjective about the implemented treatment, the participants were explicitly required to be as transparent and honest as possible in their reflections. In this light, the students were assured that their views would not in any way affect them. Also, they were encouraged to document their reflections in the Arabic language. Additionally, they were trained and often invited to openly express their opinions about various learning and assessment experiences throughout the treatment period. The rationale, as stated before, was to triangulate 
the data and obtain a more objective view on the interconnection between the treatment implemented in the study and the target research variable.

\subsection{Research Procedure}

As stated previously, there is no single agreed-upon model for portfolio development and implementation. Still, most definitions agree that any effective portfolio assessment project should comprise three major components: collection, selection, and reflection (Arter \& Spandel, 1992; Hamp-Lyons \& Condon, 2000; Paulson, Paulson, \& Meyer, 1991; Weigle, 2002). This study followed the same tips and stages throughout the treatment period. Yet, before implementing the new portfolio assessment alterations, the experimental group students were introduced to the objectives of the portfolio and the necessary procedures to be followed to achieve these objectives. Also, the students were provided with a unified portfolio template that clearly defines the objectives of each writing class, the writing assignments to be completed, and the related reflection and assessment activities. In each class, the students were required to, first, write their first drafts on a theme specified in the syllabus, second, self- and peer-assess them using the pre-specified checklists, and then sit for a short conference with the instructor before producing their final drafts. At the end of each term, students were invited to reflect upon their writings and select the best products for summative evaluation. In contrast, the control group was tested summatively without any reflection or revision opportunities. However, both groups were taught the same syllabus and evaluated using the same writing criteria: relevance and adequacy of the content, paragraph and composition organization, appropriateness and variety of vocabulary, grammar accuracy, and mechanics (MNE, 2007).

\section{FINDINGS}

\subsection{Quantitative findings}

This study started from the assumption that students assessed using portfolio-based writing assessment activities would achieve a more positive writing self-concept level than students tested using traditional summative writing tests. The statistical analysis of the data related to this hypothesis is presented in Tables 1 and 2.

Table 1. Independent Samples t-Test of the Differences in Writing Engagement Between the Experimental Group and the Control Group in the Pre-Test and the Post-Test

\begin{tabular}{|c|c|c|c|c|c|c|c|}
\hline Groups & Number & Test & Mean & $\begin{array}{l}\text { Standard } \\
\text { deviation }\end{array}$ & $\begin{array}{l}t \text { - } \\
\text { value }\end{array}$ & $\begin{array}{l}\text { Sig. } \\
\text { Value }\end{array}$ & Sig. level \\
\hline Experimental & 24 & \multirow[t]{2}{*}{ Pre-test } & 46,2083 & 10,29976 & \multirow[t]{2}{*}{,- 909} & \multirow[t]{2}{*}{,368 } & \multirow[t]{2}{*}{ Not sig. } \\
\hline Control & 24 & & 43,3333 & 11,56707 & & & \\
\hline Experimental & 24 & \multirow{2}{*}{$\begin{array}{l}\text { Post- } \\
\text { test }\end{array}$} & 49,4167 & 10,96999 & \multirow[t]{2}{*}{$-3,275$} & \multirow[t]{2}{*}{,002 } & \multirow[t]{2}{*}{ Sig. } \\
\hline Control & 24 & & 39,5833 & 9,79759 & & & \\
\hline
\end{tabular}

Table 1 summarizes the results related to students' writing self-concept before and after the study. A glance at the table above reveals that both groups had a similar level of writing self-concept before being exposed to the treatment despite the noticeable difference in favor of the experimental group. This latter began the treatment with a mean score of 46,2083 and a 
standard deviation of 10,29976, while the control group started the study with a mean score of 43,3333 and a standard deviation of 11,56707. However, although the experimental group scored a bit higher than the control group, the reported difference $(3,87$ points $)$ stays statistically insignificant at the 0.5 level $(p=, 368)$ according to the $t$-Test analysis results. These results imply that both groups possessed a relatively moderate level of writing self-concept. This level ranged between 43,3333 for the control group and 46,2083 for the experimental group. These results are very close to the midpoint of the scale, which is 45 .

Unlike the pre-test results, which confirm the equivalence of the control and the experimental groups' writing self-concept level, the post-test results indicate a statistically significant difference between the two groups at the 0.5 level $(p=, 002)$ in favor of the experimental group. While the control group obtained a total mean score of 39,5833 with a standard deviation of 9,79759, the experimental group achieved a total mean score of 49,4167 with a standard deviation of 10,96999 . That is to say that the experimental group is about 10 points away from the control group. This difference means that the experimental group outperformed the control group at the level of writing self-concept though the results of both groups stay close to the theoretical midpoint of the scale, which is 45 . Figure 6 illustrates these results graphically.

\section{Figure 1. Comparison between the mean scores of both groups in writing self- concept on the pre-test and the post-test.}



To measure the nature (positive or negative) and amount of change (significant or nonsignificant) made by each group between the pre- and post-stages of the study, the obtained results were analyzed statistically using both descriptive and inferential statistics. The results of this analysis are presented in Table 2 . 
Table 2. Independent Samples t-Test Results of the Differences in Writing Self-Concept Between the Pre-Test and the Post-Test for Each Group

\begin{tabular}{llllllll}
\hline Groups & Number & Tests & Mean & $\begin{array}{l}\text { Standard } \\
\text { deviation }\end{array}$ & $\begin{array}{l}t- \\
\text { value }\end{array}$ & $\begin{array}{l}\text { Sig. } \\
\text { Value }\end{array}$ & Sig. level \\
\hline Experimental & 24 & Pre-test & 46,2083 & 10,29976 & $-1,045$ &, 302 & Not sig. \\
\cline { 2 - 5 } & & Post-test & 49,4167 & 10,96999 & & & \\
\hline Control & 24 & Pre-test & 43,3333 & 11,56707 & 1,212 & \multirow{2}{*}{, 232} & Not sig. \\
\cline { 2 - 5 } & & Post-test & 39,5833 & 9,79759 & & & \\
& & & & & & & \\
\hline
\end{tabular}

The results in Table 2 show that the two groups' levels of writing self-concept went in two opposite directions. The control group level dropped from a mean score of 43,3333 and a standard deviation of 11,56707 in the pre-test to a mean score of 39,5833 and a standard deviation of 9,79759 in the post-test with more than 3 points of difference in favor of the pretest. The experimental group, on the other side, marked an improvement from a mean score of 46,2083 and a standard deviation of 10,29976 in the pre-test to a mean score of 49,4167 and a standard deviation of 10,96999 in the post-test with more than 3 points of difference in favor of the post-test. The $t$-Test analysis confirms that there is not a statistically significant difference at the 0.5 level between the pre-test and the post-test results for the control group in spite of the noticeable difference in favor of the former $(p=, 232)$. The same remark is true also for the experimental group whose writing self-concept score relatively, but insignificantly, improved between the pre- and the post-stages of the study $(p=, 302)$. Still, the comparison between the mean scores of the control group and the mean scores of the experimental group before and after receiving the treatment suggests that portfolio assessment has positively impacted the experimental group students' writing self-concept. Figure 2 illustrates these results graphically.

Figure 2. Comparison of the experimental and control groups' level of writing selfconcept between pre-test and post-test.

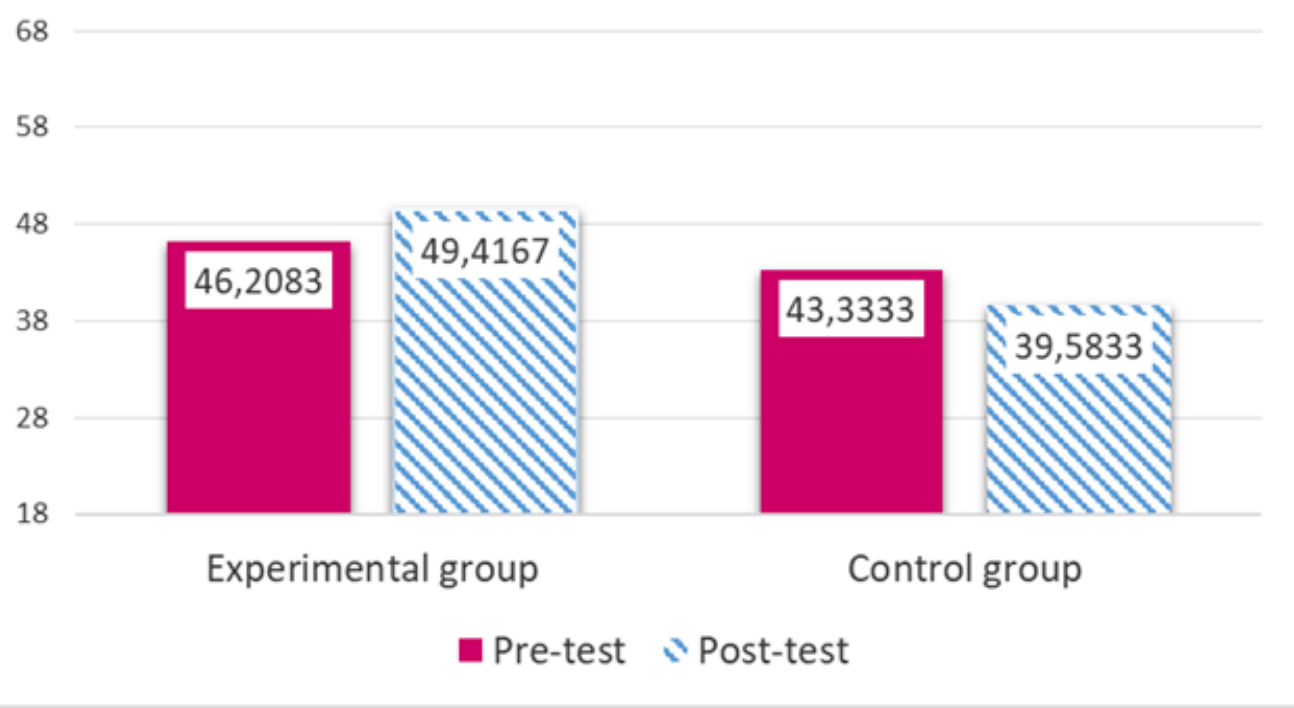




\subsection{Qualitative findings}

To enrich and double-check the study's quantitative findings, the data collected from the students' written reflections were analyzed specifically for the variable under examination. To avoid repetition and obtain an idea about the dominating tendency among the participants, the comments that express the same ideas were gathered, then presented with their frequency and percentage among the other comments. Table 4 depicts the results of this analysis.

\section{Table 3. The Coded Comments Related to Writing Self-Concept}

Comments Frequency Percentage

1. Portfolio assessment made me believe in my abilities and that I $4 \quad 16 \%$ can write in English.

2. PA enabled me to change my negative attitude toward writing. $3 \quad 11 \%$

3. Last year, I was weak in writing, but after using portfolio $1 \quad 5 \%$ assessment, I improved my writing skills.

4. In the beginning, I faced many difficulties, but now I learned 1 some characteristics of (good) writing.

5. Thanks to portfolio, I now make fewer mistakes while writing. $115 \%$

6. Writing in the portfolio is somehow easy. $\quad 1 \quad 5 \%$

\begin{tabular}{lll}
\hline 7. I find it comfortable to write in English. & 1 & $5 \%$
\end{tabular}

8. I love writing about different themes. $\quad 1 \quad 5 \%$

9. The portfolio helped me to write more quickly and easily. $\quad 1 \quad 5 \%$

\begin{tabular}{lll}
\hline 10. I started valuing writing as a skill. & 1 & $5 \%$
\end{tabular}

\begin{tabular}{lll}
\hline 11. Portfolio assessment made me like English. & 1 & $5 \%$
\end{tabular}

\begin{tabular}{lll}
\hline 12. I Lack the necessary vocabulary to write. & 1 & $5 \%$
\end{tabular}

\begin{tabular}{lll}
\hline 13. I find it hard to link ideas. & 1 & $5 \%$
\end{tabular}

\begin{tabular}{lll}
\hline 14. I feel psychologically distressed. & 2 & $8 \%$
\end{tabular}

15. I find it difficult to write. $\quad 1 \quad 5 \%$

\begin{tabular}{lll}
\hline 16. Writing is difficult. & 1 & $5 \%$
\end{tabular}

$\begin{array}{lll}\text { Total } & 22 & 100 \%\end{array}$

The students' qualitative answers in Table 3 above include several comments relevant to writing self-concept. These comments show how students perceived portfolio assessment to affect their writing self-concept. As can be perceived holistically, it seems that students largely perceived portfolio assessment to have a positive effect on their writing self-concept though a few others still focused on the linguistic and psychological difficulties they encountered while writing (items 12, 13,14,15, and 16), which is quite natural. As echoed by Chapman and 
Tunmer (1995), "young children can hold positive self-perceptions of ability while also having self-perceptions of difficulty in academic work" (p. 154). 16\% of the students explicitly stated that portfolio assessment raised their writing confidence, and 11\% acknowledged that it helped change their negative attitudes toward writing. Other proportions of the students expressed this positive tendency using various phrases with a frequency of $5 \%$ for each one of them. These percentages might indicate the potential of portfolio assessment to address the self-needs of different learners. One proportion of the students centered on their perceptions of their writing abilities before and after receiving portfolio assessment (items 3, 4 \& 5). Another proportion of students focused on the attitudinal and affective side of portfolio-based writing experiences (items 6, 7, 8, and 10). One student emphasized how portfolio affected his writing speed (9).

\section{DISCUSSION}

The current study aimed at examining the impact of portfolio assessment on the Moroccan EFL students' writing self-concept. Based on the insights drawn from the existing literature, it was hypothesized that the students assessed through portfolios would develop a more positive writing self-concept level than those tested through summative tests. The collected quantitative and qualitative evidence supports this hypothesis, suggesting that portfolio assessment practices significantly impacted the students' writing self-concept compared to traditional summative writing achievement tests (see Table 1). This is in spite of the fact that the experimental group did not actually mark a statistically significant improvement between the pre- and the post-stages of the study according to the results of the $t$-Test analysis (see Table 2). Nevertheless, interpreting these findings in light of the students' reflections confirms that there was a remarkable improvement in their writing self-concept. The reported comments included numerous statements and phrases that all signify a substantial improvement in students' writing self-concept after exposure to portfolio assessment alterations (see Table 3).

This significant difference between the portfolio and non-portfolio assessment groups is reported in several other studies like Burch (1999) and Nicolaidou (2012), and it can be attributed to several factors. First, it seems, as depicted from the post-treatment reflections, that portfolio assessment has dramatically changed the students' perceptions of assessment and its role in the learning/writing process. As expressed by one of the students: "I think that this booklet is better than traditional tests. I do not view it as a means for accumulating grades, but I see it as a way to express and organize my ideas about a given subject/topic, which was very exciting". Another student concluded his experience with portfolio assessment, stating: "... the most important thing is that I learned [a lot of] things from this assessment". Second, testing and judging students' learning at every single assessment occasion proved to be highly threatening for them. Accordingly, the use of process-oriented tools like portfolio assessment with timely, more detailed, and motivating feedback, as was the case in the present study, might be beneficial for lowering students' writing anxiety and enhancing their writing self-concept (Nezakatgoo, 2011; Nosratinia \& Abdi, 2017; Peterson \& McClay, 2010). Hamp-Lyons and Condon (2000) contend that one of the most attractive features of portfolio assessment is "delayed evaluation", giving students and teachers more time for revision and generating a "success now" atmosphere that helps both of them feel better about the learning experiences. Third, portfolio assessment, as already underlined, is based on the idea of growth and development. The portfolio assessment model followed in this study appears to support the students to achieve that improvement through drafting, redrafting, and reflecting upon their work. More important, however, is that it raised their awareness to that improvement. This is clearly mirrored in the students' written reflections, which included explicit statements about how portfolio assessment helped them improve their writing self-concept between the pre- and the post-stages of the study (see Table 3). 
The moderate, non-significant writing self-concept improvement in the portfolio assessment group students between the pre and the post-stages of the study can be accounted for by considering at least two major interrelated factors. The first one has to do with the nature of the construct examined, and the other has to do with the duration of the experiment. First, although writing self-concept was defined in the current study as a dynamic construct, certain aspects of it still have been found to be resilient to change (Mercer, 2011). This is what Mercer (2009) came to in her examination of the foreign language self-concept of a case study in a qualitative two-year longitudinal study (cited in Mercer, 2011). Mercer reported that what she termed the more central, 'core', foreign language self-beliefs of the student did not appear to change over the two years, while the more task-specific aspects of her self-concept were quite dynamic. More interesting is that the degree to which the foreign language self-concept of that student changed seemed to depend primarily on its initial degree of complexity and that learner's amount of experience in the domain. Thus, it seems quite plausible not to expect a great change in the Moroccan EFL students writing self-concept, too, given the complexity of the construct examined, the limited EFL experience of these students, and the prevalent negative attitude that EFL learners usually hold toward writing. These factors could be added to the duration of the treatment, which, as was the case in Mercer's study, might not have been long enough to engender the level of writing self-concept improvement desired. Therefore, the level of improvement obtained in this study might, in fact, be considered a good indicator of the fruitfulness and the effectiveness of portfolio assessment in terms of building and enhancing students' writing self-concept.

\section{CONCLUSION}

This study investigated the role of portfolio-based assessment practices in promoting a more positive writing self-concept among the Moroccan EFL students. The analysis and interpretation of the collected data reveal that portfolio assessment can play a pivotal role in building and maintaining a more positive writing self-concept than traditional achievement tests. Although the quantitative data did not show a statistically significant improvement in the students' writing self-concept between the pre- and post stages of the study, it did show a substantial difference between the portfolio-assessment students and the traditional assessment ones. Additionally, the qualitative data showed a remarkable change in the students' perception of their writing abilities and attitudes toward writing and assessment after benefiting from the treatment. These results suggest that portfolio assessment practices might be utilized for creating a more comfortable learning and assessment atmosphere where students feel better about themselves and their work. As already stated that there is a strong relationship between students' self-perceptions and the quality of their learning. The use of portfolio assessment, as evidenced in this study and many other ones, can help students alleviate the negative feelings of anxiety and apprehension and form a fairer and more positive picture about their efforts and progress.

\section{REFERENCES}

Abouabdelkader, H., \& Bouziane, A. (2016). The teaching of EFL writing in Morocco: Realities and challenges. In A. Ahmed \& H. Abouabdelkader (Eds.), Teaching EFL Writing in the 21st Century Arab World: Realities \& Challenges (pp. 35-68). Palgrave Macmillan, London. Doi: 10.1057/978-1-137-46726-3.

Arter, J. A., \& Spandel, V. (1992). Using portfolios of student work in instruction and assessment. Educational measurement: Issues and practice, 11(1), 36-44.

Badiozaman, A. (2012). A study on the relationship between Malaysian learners' self-concept in academic writing and their engagement in one higher learning institution: a dissertation presented in partial fulfilment of the requirements for the degree of Doctor of Philosophy in Education at Massey University, Palmerston North, New 
Zealand (Doctoral dissertation, Massey University). Retrieved from: https://mro.massey.ac.nz/handle/10179/4090

Badrasawi, K. J., Zubairi, A., \& Idrus, F. (2016). Exploring the relationship between writing apprehension and writing performance: A qualitative study. International Education Studies, 9(8), 134-143.

Boening, C. H., Anderson, L. A., \& Miller, M. T. (1997). Writing Apprehension and Academic Achievement among Undergraduate Honors Students.

Bouziane, A., \& Zyad, H. (2018). The Impact of Self and Peer Assessment on L2 Writing: The Case of Moodle Workshops. In A. Ahmed \& H. Abouabdelkader (Eds.), Assessing EFL Writing in the 21st Century Arab World: Revealing the unknown (pp. 111-135). Palgrave Macmillan, Cham. Doi: 10.1007/978-3-319-64104-1.

Burch, C. B. (1999). Inside the portfolio experience: The student's perspective. English education, 32(1), 34-49.

Byrne, B. M. (1996). Measurement and instrumentation in psychology. Measuring self-concept across the life span: Issues and instrumentation. Washington, DC, US: American Psychological Association.

Byrne, B. M. (1984). The general/academic self-concept nomological network: A review of construct validation research. Review of educational research, 54(3), 427-456.

Chapman, J. W., \& Tunmer, W. E. (1995). Development of young children's reading selfconcepts: An examination of emerging subcomponents and their relationship with reading achievement. Journal of Educational Psychology,87(1), 154. Doi: https://doi.org/10.1037/0022-0663.87.1.154.

Creswell, J. W. (2005). Educational research: Planning, conducting, and evaluating quantitative and qualitative research. ( $4^{\text {th }}$ ed.). New Jersey: Pearson Merrill.

Dawson, C. (2007). A Practical guide to research methods: A user-friendly manual for mastering research techniques and projects. ( $3^{\text {rd }}$ ed.). British Library Cataloguing in Publication Data.

Elif, G. E. N. Ç., \& Yayli, D. (2019). The second language writing anxiety: the perceived sources and consequences. Pamukkale Üniversitesi Ĕgitim Fakültesi Dergisi, 45(45), 235-251.

Erkan, D. Y., \& Saban, A. İ. (2011). Writing performance relative to writing apprehension, self-efficacy in writing, and attitudes towards writing: A correlational study in Turkish tertiary-level EFL. The Asian EFL Journal Quarterly, 13(1), 164-192

Ghaicha, A., \& Omarkaly, E. (2018). Alternative assessment in the Moroccan EFL classrooms: teachers' conceptions and practices. Higher Education of Social Science, 14(1), 56-68. DOI:10.3968/10161

Hamp-Lyons, L., \& Condon, W. (2000). Assessing the portfolio: Principles for practice. Theory, Research. Cresskill, NJ: HamptonPress. 
Harter, S. (1998). The development of self-representations. In W. Damon (Series Ed.) \& N. Eisenberg (Vol. Ed.), Handbook of Child Psychology (5th ed., Vol. 3, pp. 553-618). New York: Wiley.

Hyland, K. (2003). Second language writing. UK: Cambridge University Press.

Kathpalia, S. S., \& Heah, C. (2008). Reflective writing: Insights into what lies beneath. Relc Journal, 39(3), 300-317. Doi: 10.1177/0033688208096843.

Klenowski, V. (2002). Developing portfolios for learning and assessment: processes and principles. Routledge Falmer, London.

Krashen, S. (1988). Second Language Acquisition and Second Language Learning. New York: Prentice Hall.

Lado, R. (2000). Language testing: Writing in a foreign language. Longman.

Lucas, R. I. G. (2008). A Study on Portfolio Assessment as an Effective Student SelfEvaluation SchemeZ. The Asia-Pacific Education Researcher, 16(1), 23-32. Doi=10.1.1.610.6219

Maslow, A. H. (1943). A theory of human motivation. Psychological Review, 50(4), 370-96.

Melouk, M. (2001). The state of EFL evaluation in Morocco: The testers and teachers' opinions. In A. Zaki \& M. Naji, (Eds). The Teaching and Assessment of English for Global Purposes. Paper presented at MATE proceedings, Essaouira (pp. 41-51). Rabat: MATE.

Mercer, S. (2011). Towards an understanding of language learner self-concept (Vol. 12). Springer Science \& Business Media.

Ministry of National Education. (2007). English language guidelines for secondary schools: common core, first year, and second year baccalaureate. Rabat: Author.

Nezakatgoo, B. (2011). The Effects of Portfolio Assessment on Writing of EFL Students. English language teaching, 4(2), 231-241. Doi: 10.5539/elt.v4n2p231.

Nicolaidou, I. (2012). Can process portfolios affect students' writing selfefficacy?. International Journal of Educational Research, 56, 10-22. Doi: 10.1016/j.ijer.2012.08.002.

Nosratinia, M., \& Abdi, F. (2017). The comparative effect of portfolio and summative assessments on EFL learners' writing ability, anxiety, and autonomy. Journal of Language Teaching and Research, 8(4), 823-834. Doi: 10.17507/j1tr.0804.24.

Ouakrime, M. (2000). An argument for a More Formative Approach to Assessment in ELT in Morocco. In A. Zaki (Ed). The New Education Reform in Morocco: The role of English. Proceedings of the XXth Annual MATE conference, Kenitra (pp. 97-107). Rabat: MATE.

Ozer, O., \& Tanriseven, I. (2016). The effect of portfolio-based writing assessment on the development of writing skills of EFL students. International Online Journal of Educational Sciences, 8(3). Doi: 10.15345/iojes.2016.03.004. 
Öztürk, H., \& Çeçen, S. (2007). The effects of portfolio keeping on writing anxiety of EFL students. Journal of Language and Linguistic Studies, 3(2), 218-236.

Pajares, F. (2003). Self-efficacy beliefs, motivation, and achievement in writing: A review of the literature. Reading \&Writing Quarterly, 19(2), 139-158.

Paulson, F. L., Paulson, P. R., \& Meyer, C. A. (1991). What makes a portfolio a portfolio. Educational leadership, 48(5), 60-63.

Peterson, S. S., \& McClay, J. (2010). Assessing and providing feedback for student writing in Canadian classrooms. Assessing writing, 15(2), 86-99.

Qadir, S. M., Bensen Bostanci, H., \& Kurt, M. (2021). Writing Apprehension Among English as a Foreign Language Postgraduate Students. SAGE Open, 11(2), 21582440211007121.

Rogers, C. R. (1957). Becoming a Person. Boston: Houghton Mifflin.

Rosenberg, M. (1965). Society and the adolescent self-image. Princeton university press.

Saeed, M. A., Alharbi, M. A., \& Yassin, A. A. (2021). Sustaining Synchronous Interaction Effectiveness in Distance Writing Courses: A Mixed Method Study in a KSA University. Sustainability, 13(24), 13675.

Shavelson, R. J., Hubner, J. J., \& Stanton, G. C. (1976). Self-concept: Validation of construct interpretations. Review of educational research,46(3), 407-441. Doi: $\underline{10.3102 / 00346543046003407 .}$

Weigle, S. C. (2002). Assessing Writing. Cambridge University Press.

Valentine, J. C., DuBois, D. L., \& Cooper, H. (2004). The relation between self-beliefs and academic achievement: A meta-analytic review. Educational psychologist, 39(2), 111133.

Yassin, A. A., \& Razak, N. A. (2018). Investigating Foreign Language Learning Anxiety among Yemeni University EFL Learners: A Theoretical Framework Development. English Language Teaching, 11(10), 38-51. 